\author{
한국연안 해조류 생물량의 연간 변동 양상: \\ 제주도 문섬지역 \\ 고영욱 ${ }^{1} \cdot$ 성건희 1 . 이창호 ${ }^{1} \cdot$ 김현희 $^{1} \cdot$ 최동문 ${ }^{1} \cdot$ 고용덕 ${ }^{2} \cdot$ 이욱재 ${ }^{3}$. \\ 고형범4 ${ }^{4}$ 옥정현 ${ }^{5} \cdot$ 정익교 $^{6} \cdot$ 김정하 $^{1 *}$ \\ (1성균관대학교 생명과학과, ${ }^{2}$ 고스다이브시스템, ${ }^{3}$ 제주생물종다양성연구소, ${ }^{4}$ 제주특별자치도 해양수산자원연구소, \\ ${ }^{5}$ 부산대학교 해양연구소, ${ }^{6}$ 부산대학교 지구환경시스템학부)
}

\title{
Temporal Variations of Seaweed Biomass in Korean Coasts: Munseom, Jeju Island
}

\section{Young Wook Ko ${ }^{1}$, Gun Hee Sung ${ }^{1}$, Chang Ho Yi ${ }^{1}$, Hyun Hee Kim ${ }^{1}$, Dong Mun Choi ${ }^{1}$, Yong Deok $\mathrm{Ko}^{2}$, Wook Jae Lee ${ }^{3}$, Hyoung-Bum Koh ${ }^{4}$, Jung Hyun Oak ${ }^{5}$, Ik Kyo Chung ${ }^{6}$ and Jeong Ha Kim ${ }^{1 *}$}

\author{
${ }^{1}$ Department of Biological Science, Sungkyunkwan University, Suwon 440-746, Korea \\ ${ }^{2}$ Ko's Dive System, 1107, Gunip-Dong, Jeju 690-050, Korea \\ ${ }^{3}$ Jeju Biodiversity Research Institute, HiDI, Jeju 690-121, Korea \\ ${ }^{4}$ Jeju Special Self-Governing Province Fisheries Resources Research Institute, Jeju 699-915, Korea \\ ${ }^{5}$ Marine Research Institute, Pusan National University, Busan 609-735, Korea \\ ${ }^{6}$ Division of Earth Environmental System, Pusan National University, Busan 609-735, Korea
}

\begin{abstract}
Seaweed biomass was estimated using a nondestructive method in the rocky subtidal zones in Munseom, Jeju Island, Korea from July 2006 to April 2008. Seasonal samplings were done at the depth of 1, 5, $10 \mathrm{~m}$ using $50 \times 50 \mathrm{~cm}$ quadrat. Mean biomass was comprised of 2,784 $\mathrm{g}$ wet w $\mathrm{m}^{-2}$ and the biomass values varied seasonally from 1,176 $\mathrm{g}$ wet wt $\mathrm{m}^{-2}$ to $4,217 \mathrm{~g}$ wet $\mathrm{wt} \mathrm{m}^{-2}$ with the highest point in April. Biomass reached maximum at $5 \mathrm{~m}$ depth in spring, but was shifted to $10 \mathrm{~m}$ depth in summer. Common seaweeds appeared year round in Munseom were Codium minus, Ecklonia cava, Sargassum spp., articulated corallines and Plocamium telfairiae. Among them, E. cava showed the highest biomass (average of 1,288 $\mathrm{g}$ wet $\mathrm{wt} \mathrm{m}^{-2}$ ), comprising $48 \%$ of total biomass. Only 12 species' biomass covered $98 \%$ of total value, which indicated the contribution of few common species to algal community. Seaweed biomass in Munseom represented one of the highest values in coastal regions in Korea.
\end{abstract}

Key Words: biomass, Munseom, nondestructive method, regression, seaweed, subtidal zone

서 론

해양생태계에서 해조류는 1 차 생산자로서의 중요한 가치 를 가질 뿐만 아니라 해양 무척추동물과 어류의 서식처와 산 란처를 제공하는 요람으로서 매우 중요한 의미를 가진다. 이 러한 연안에 서식하는 해조류 분포와 군집구조 분석은 연안

*Corresponding author (jhkimbio@skku.ac.kr)
생태계의 다양성과 생산성을 평가하는 중요한 기준으로 활 용될 수 있다. 특히 해양생태계에서 높은 생물다양성과 생산 성으로 가치를 가지는 천해 조하대의 해조군집에 대한 연구 는 해양환경의 보전과 지속 가능한 이용을 위한 필수적인 분 야이다.

한국 제주연안의 해조류에 대한 연구는 $\operatorname{Kang}(1960)$ 의 연 구에서 153종이 보고된 이래 해조분포(이 1974; 이와 이 1976 ; Lee 1976; 이와 이 1982 ; 윤 1985 ; 부 1988 ; 김 1991) 와 생태분야(강 등 1993; Park et al. 1994; 김과 박 1997)에 
대한 연구가 수행되었다. 그러나 제주도는 해양식물자원의 보물섬(김 1991)이라고 할 만큼 다양성과 풍부함을 갖추고 있음에도 불구하고 제주 연안의 여러 지역에 대한 해조군집 에 관한 연구는 미흡한 실정이다. 해조군집의 구조에 관한 선행연구(고 1983; 고와 성 1983; 최 등 1994; Kim and Lee 1995; 최 등 2006)에서 종 구성과 분포, 생물량에 관한 언급 은 있으나 이러한 연구들은 해조군집의 지속적인 생물량 평 가를 목적으로 하는 연구라기 보다는 군집의 종조성을 제시 하고 생물량 평가를 부수적인 데이터로 제시하였다. 생물량 조사방법 또한 파괴적 방법(destructive sampling)에 의존하 였다.

연구지역인 제주도 문섬은 2000년 7월 18일 천연기념물 제421호로 지정되었으며 문화재청은 이 지역을 천연보호지 역으로 관리하고 있다. 주변 해역은 다양한 해양무척추동물 과 어류, 해조류가 서식하고 있는 연구가치가 매우 높은 지 역이다. 따라서 해조류의 분포뿐만 아니라 해조군집의 생물 량을 파악하는 것은 이 지역 해조군집의 생산성과 다양한 생 물의 서식처로서의 생태학적 가치를 이해하는 것이다. 이에 본 연구는 자연군집의 훼손을 최소화하는 방법을 적용하여 제주도 문섬 조하대 해조군집의 생물량을 조사하고 계절적 변화 및 연간 변동양상을 파악하고자 하였다.

\section{재료 및 방법}

본 연구에서는 제주도 문섬 일대(Fig. 1)의 조하대를 2006 년 7월부터 2008년 4월까지 3개월 간격으로 계절별 조하대 조사를 Scientific SCUBA-diving을 이용하여 수행하였다. 해 조류 군집조사는 수심 $1 \mathrm{~m}, 5 \mathrm{~m}, 10 \mathrm{~m}$ 에 $50 \mathrm{~cm} \times 50 \mathrm{~cm}$ 방형 구를 무작위적으로 각각 5 개씩 지정 (random point sampling, 5 replicates)하여 출현종의 피도를 구하였으며 감 태(Ecklonia cava), 미역(Undaria pinnatifida), 모자반 속 (Sargassum spp.)과 같은 대형 해조류는 방형구내 개체수와 개체별 길이 · 등급(길이 · 등급 $1<10 \mathrm{~cm}<$ 길이 · 등급 $2<20$ $\mathrm{cm}$ < 길이 - 등급 $3<30 \mathrm{~cm} \cdots)$ 을 구하는 비파괴적인 방법 (nondestructive sampling; Littler and Littler 1985)을 적용 하였다. 무작위적 방형구 지정 시 해조군집이 존재하는 암반 을 기준으로 하였으며 해조류가 없는 모래기질이나 방형구 면적보다 작은 크기의 암반은 제외하였다. 종생물량 추정을 위한 해조류의 채취는 반복적인 조사로 인한 해조군집의 훼 손을 최소화하기 위하여 매 조사시기 마다 수심별 지정한 5 개의 방형구 중 대표성을 가지는 1 개의 방형구내 출현 해조 류를 전량 채취하여 현장에서 실험실로 운반하였다. 운반된 시료들은 부착잡물들을 제거한 후 물기를 제거하고 습중량 을 $0.1 \mathrm{~g}$ 수준까지 측정하였다.

군집생물량은 해조 종별 피도 또는 길이 · 등급에 대한 습

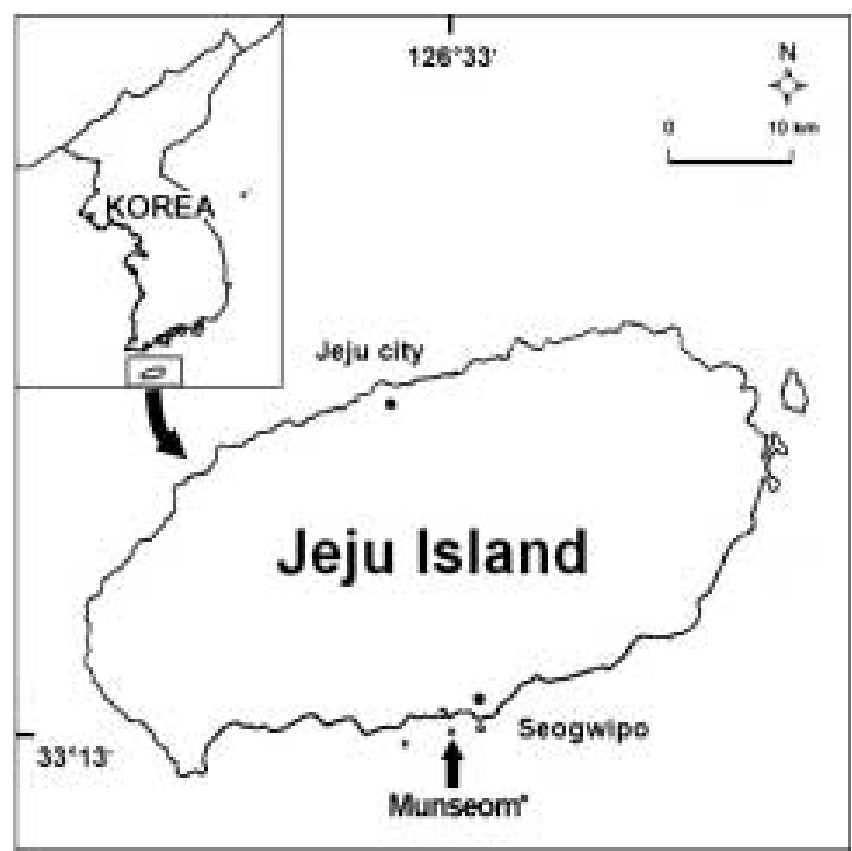

Fig. 1. The study site on the south coast of Jeju Island, Korea.

중량의 회귀공식을 도출하고 비파괴적인 방법을 통해 조사 된 자료에 반영하여 산출하였으며 단위면적 당 무게 (g wet $\mathrm{wt} \mathrm{m}^{-2}$ )로 환산하였다. 종생물량 산출에 이용된 회귀함수는 제주도 연안에서 채집된 해조류에 대한 회귀분석 자료(고 등 2008)를 이용하였다.

종별 우점도를 조사하기 위하여 단위면적당 산출된 군집 생물량에 대한 각 종별 생물량을 백분율 $(\%)$ 로 환산하여 우 점종 $(30 \%)$ 과 준우점종 $(10-30 \%)$ 으로 판정하였다(김과 허 1988).

\section{결과 및 고찰}

제주도 문섬 조하대에서 2년에 걸쳐 조사된 해조류는 녹 조류 8 종, 갈조류 18 종, 홍조류 20 종으로 총 46 종의 해조류 가 관찰되었다. 강 등(1993)은 문섬 조하대 수심 $25 \mathrm{~m}$ 까지 조사한 결과 39종의 해조류를 채집 · 동정하였으나 이번 조 사는 수심 $10 \mathrm{~m}$ 까지 조사한 결과로서 여름 출현종이 24종으 로 기존의 연구와 차이를 보였다. 그러나 본 연구는 조하대 해조류의 군집생물량 조사를 목적으로 하여 조사시 $1 \%$ 미만 의 피도를 보이는 종들에 한해서는 기록에서 배제하였으므 로 조사결과인 46종보다 더 많은 종들이 분포할 것으로 예상 되며 여름 출현종 역시 과소평가되었을 것으로 판단된다.

조사된 46 종의 해조류 중 회귀분석을 통하여 종생물량으 로 환산된 종들은 총 24 종으로 단위 면적당 평균 군집생물량 은 2,784 $(1,176-4,217) \mathrm{g}$ wet wt $\mathrm{m}^{-2}$ 로 나타났다(Table 1). 기존의 조하대 해조군집에 관한 생물량 연구들은 대부분 건 
Table 1. Seasonal changes in biomass of algal species in Munseom, Jeju Island (Unit: g wet wt $\mathrm{m}^{-2}$ )

\begin{tabular}{|c|c|c|c|c|c|c|c|c|}
\hline \multirow{2}{*}{$\begin{array}{l}\text { Year } \\
\text { Species / Season }\end{array}$} & \multicolumn{2}{|c|}{2006} & \multicolumn{4}{|c|}{2007} & \multicolumn{2}{|c|}{2008} \\
\hline & Summer & Autumn & Winter & Spring & Summer & Autumn & Winter & Spring \\
\hline Dictyopteris prolifera & & & & & 66 & & 11 & \\
\hline Enteromorpha prolifera & & & & & & 2 & 26 & 76 \\
\hline Ecklonia cava & 939 & 2,060 & 689 & 1,834 & 1,380 & 802 & 1,627 & 2,011 \\
\hline Plocamium telfairiae & 20 & 30 & 9 & 39 & 24 & 19 & 93 & 39 \\
\hline Ulva pertusa & 3 & & & & & & & \\
\hline Codium minus & 6 & 6 & 10 & 38 & 15 & 49 & 28 & 62 \\
\hline Galaxaura falcate & 2 & & 8 & 2 & 1 & 1 & & 11 \\
\hline Grateloupia spp. & $<1$ & & & & & & & 20 \\
\hline Codium adhaerens & & & & & 3 & & 3 & \\
\hline Cladophora wrightiana & & 1 & 1 & & 8 & 1 & & \\
\hline Sargassum spp. & 23 & 72 & 76 & 903 & 116 & 185 & 305 & 147 \\
\hline Undaria pinnatifida & & & & 212 & & & & 284 \\
\hline Padina arborescens & 1 & & 5 & 3 & 3 & 1 & 8 & 24 \\
\hline Colpomenia sinuosa & & & & 4 & & & & 61 \\
\hline Acanthopeltis japonica & & & & 1 & 10 & 4 & 3 & 1 \\
\hline Gelidium elegance & 5 & & 30 & 12 & & & 12 & \\
\hline Grateloupia angusta & & & 1 & 13 & 4 & 28 & 2 & 30 \\
\hline Zonaria diesingiana & & 4 & 4 & 6 & 13 & 8 & 13 & 12 \\
\hline Chondrus ocellatus & 186 & & & 45 & 20 & & & 3 \\
\hline Dilophus okamurae & & & & & 1 & 7 & 4 & 6 \\
\hline Peyssonnelia capensis & & 7 & 2 & 20 & 16 & 7 & 22 & 21 \\
\hline Callophyllis japonica & & & & & & & & 5 \\
\hline Articulate coralline algae & 738 & 299 & 341 & 959 & 860 & 1,513 & 1,056 & 1,397 \\
\hline Spatoglossum pacificum & & & & & & & & 7 \\
\hline Total & 1,923 & 2,479 & 1,176 & 4,091 & 2,540 & 2,627 & 3,215 & 4,217 \\
\hline
\end{tabular}

*All data shown were estimated using regression

중량을 측정하여 본 연구와 직접 비교하기는 어려우나 유 (2003)의 연구에서 영일만 조하대 두 지역의 군집생물량이 $152 \mathrm{~g}$ dry wt m${ }^{-2}$ 와 $84 \mathrm{~g} \mathrm{dry} \mathrm{wt} \mathrm{m}^{-2}$ 로 조사되었으며 부산 용 호동 일대의 조간대와 조하대의 계절별 군집생물량이 $1,241-$ $1,648 \mathrm{~g}$ wet wt m $\mathrm{m}^{-2}$ 으로 보고된 바 있다. 조하대의 습중량을 조사한 사례는 남해안 일대의 섬들을 대상으로 여름에 조사 가 이루어졌으며 10 개 도서지역 (홍도, 거문도, 여서도, 관탈 도, 추자도, 욕지도, 비진도, 문섬, 만재도, 소리도)의 조하 대 해조군집의 생물량의 분포가 980-2,350 g wet wt m-2으로 조사되었다. 특히 문섬의 경우 $1,570 \mathrm{~g} \mathrm{wet} \mathrm{wt} \mathrm{m}^{-2}$ 으로 조사 되었으며 가장 높은 군집생물량을 보인 곳은 추자도로써 $2,350 \mathrm{~g}$ wet $\mathrm{wt} \mathrm{m} \mathrm{m}^{-2}$ 에 달하는 것으로 보고되었다(강 등

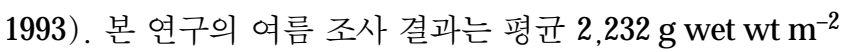
으로 추자도를 제외한 기존의 조하대 연구결과보다 대개 높 은 군집생물량을 보였다.

조사기간 동안 평균 종생물량이 가장 높은 종은 감태로 단 위면적 당 $1,288 \mathrm{~g} \mathrm{wet} \mathrm{wt} \mathrm{m}^{-2}$ 으로 산출되어 조사지역 내 군 집생물량의 $48 \%$ 를 차지하였다. 또한 종생물량으로 환산된
24종 중 단위면적 당 $10 \mathrm{~g}$ wet $\mathrm{wt} \mathrm{m} \mathrm{m}^{-2}$ 이상으로 조사된 12 종 의 생물량이 차지하는 비중은 $98 \%$ 인 것으로 조사되었다. 이 는 군집을 구성하는 주요종의 생물량 추정으로도 전체 해조 군집에 대한 현존량을 추정할 수 있음을 시사하는 바이다. 아울러 남(1986)과 이와 장(1989)은 해조군집 내 갈조류의 종생물량이 군집 전체의 생물량에서 대부분을 차지한다고 하였으며, 본 연구에서도 감태와 모자반 속, 미역의 종생물 량이 전체 군집생물량의 $57 \%$ 를 차지함으로써 대형 갈조류 의 정확한 종생물량 산출이 매우 중요한 과정임을 알 수 있 다. 따라서 본 연구에서 적용한 대형 해조류의 길이 - 등급 별 개체수 자료 수집 방법의 적절성은 추후 다른 방법과의 비교 검토를 통해 명확해 질 것으로 판단된다.

지금까지 비교한 평균 군집생물량은 조사기간 동안 수집 된 모든 자료를 반영하는 결과이나 조사시점의 기상상황으 로 인하여 2006년 7월과 2007년 4월, 10 월의 $1 \mathrm{~m}$ 수심의 자 료는 수집되지 못하였다. 따라서 조사지역 군집생물량의 계 절성 및 연간변동의 비교는 $5 \mathrm{~m}$ 와 $10 \mathrm{~m}$ 의 자료를 이용하여 분석하였다(Figs 2,3 ). 조사시기별 군집생물량의 변동은 
Table 2. Dominant and subdominant species in Munseom.

\begin{tabular}{lllll}
\hline Year & Season & & \multicolumn{2}{l}{ Dominant and subdominant species } \\
\hline 2006 & Summer & Ecklonia cava* & Articulate coralline algae* & Chondrus ocellatus \\
& Autumn & Ecklonia cava* & Articulate coralline algae & \\
\hline \multirow{2}{*}{2007} & Winter & Ecklonia cava* & Articulate coralline algae* & \\
& Spring & Ecklonia cava* & Articulate coralline algae & Sargassum spp. \\
& Summer & Ecklonia cava* & Articulate coralline algae* & \\
& Autumn & Articulate coralline algae* & Ecklonia cava* & Sargassum spp. \\
\hline \multirow{2}{*}{2008} & Winter & Ecklonia cava* & Articulate coralline algae* & Sargassum spp. \\
& Spring & Ecklonia cava* & Articulate coralline algae* & \\
\hline
\end{tabular}

*: dominant species

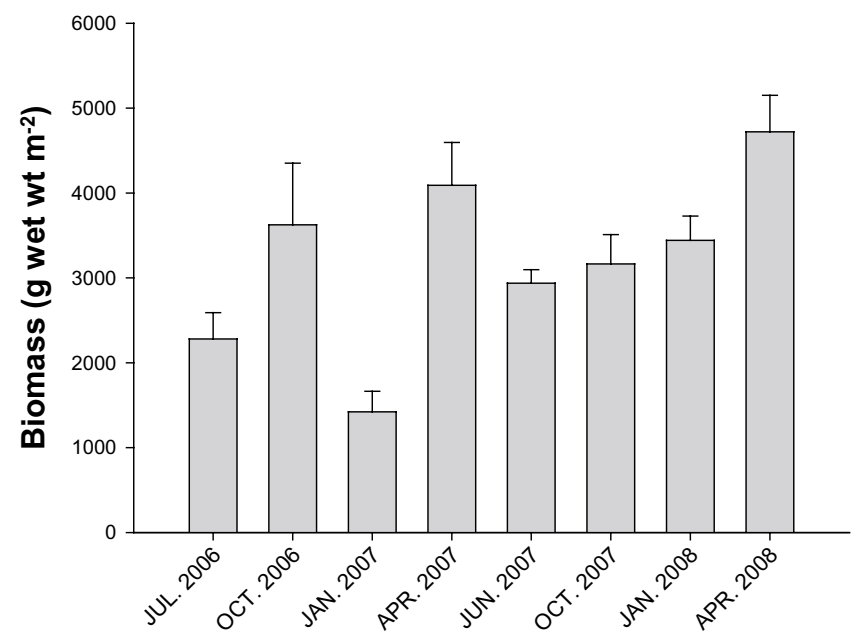

Fig. 2. Seasonal changes in biomass of all algal species in Munseom. Data are the mean + SE of 5 replicate at $5 \mathrm{~m}$ and $10 \mathrm{~m}$ depth.

$1,422-4,721 \mathrm{~g}$ wet wt m $\mathrm{m}^{-2}$ 의 넓은 범위를 보였으며 계절별로 는 봄과 가을에 풍부하고 여름과 겨울에 감소하는 것으로 나 타났다. 또한 겨울인 2007년 1월의 군집생물량은 전체 조사 시기중 가장 낮은 $1,422 \mathrm{~g}$ wet wt $\mathrm{m}^{-2}$ 로 조사되었으나, 2008 년 1월에는 전체 군집생물량 평균보다 높은 $3,441 \mathrm{~g}$ wet wt $\mathrm{m}^{-2}$ 으로 추산되어 계절적 차이와 동시에 연간 변동도 있음 을 확인할 수 있다. 이러한 군집생물량의 계절적 특성은 여 러 연구에서 언급되었으며 김 등(1996)의 연구에서는 군집 생물량이 봄에 최대, 겨울에 최소로 본 연구와 일치하는 결 과를 나타내었다. 그러나 박 등(1997)의 연구에서 신지도 동 고리 지역은 봄에 최대값을 보였고 10 여 $\mathrm{km}$ 떨어진 신지도 강독 지역은 겨울에 최대값을 보여 인접한 지역에서도 계절 성에 차이가 있음을 보여주었다. 또한 부산 용호동 일대에서 조사된 남과 김(1999)의 조사에서는 여름이 가장 높고 봄이 가장 낮았으며 태안반도에서 수행된 이와 장(1989)의 조간 대 연구는 가을이 최대, 봄이 최소를 보여 해조군집 생물량 의 계절성은 매우 다양한 것으로 알려져 있다. 본 연구에서
도 계절성의 연간변동을 보였으며 이러한 연간변동은 폭풍, 강수, 해류의 변화 등의 비생물학적인 요인과 더불어 고착성 해양무척추 동물과의 공간 경쟁, 초식자의 섭식 등 생물학적 요인이 다양한 원인이 되어 발생하는 것으로 판단된다. 수심 $5 \mathrm{~m}$ 와 $10 \mathrm{~m}$ 에서 조사된 주요 7종은 감태 $(1,030-3,091 \mathrm{~g}$ wet $\mathrm{wt} \mathrm{m}^{-2}$ ), 유절석회조류 (Articulated coralline algae, 176$1,495 \mathrm{~g}$ wet wt $\mathrm{m}^{-2}$ ), 모자반 속(35-903 g wet wt $\mathrm{m}^{-2}$ ), 미역 (0-212 g wet wt $\mathrm{m}^{-2}$ ), 진두발(Chondrus ocellatus; 0-268 g wet $\mathrm{wt} \mathrm{m}^{-2}$ ), 구슬청각(Codium minus, 9-93 $\mathrm{g}$ wet $\mathrm{wt} \mathrm{m}^{-2}$ ), 참곱슬이 (Plocamium telfairae, $13-59 \mathrm{~g}$ wet $\mathrm{wt} \mathrm{m}^{-2}$ )의 순으로 높은 종생물량을 보였으며 감태, 유절석회조류, 모자반 속은 연중 우점하는 패턴을 보였으나 미역과 진두발은 계절에 따 라 종생물량의 차이를 보였다(Fig. 3). 계절별 우점종과 준우 점종은 Table 2에 제시된 바와 같이 갈조식물 감태가 전 조 사기간에 걸쳐 우점하는 것으로 조사되었다. 감태의 성장이 멈추고 끝녹음이 진행되는 가을 시기에 일부 유절석회조류 의 종생물량이 더 높게 조사되었으나 이 시기에도 감태는 여

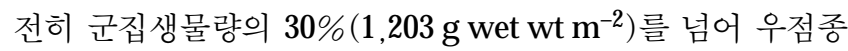
으로 구분되었으며 모자반 속과 진두발이 일부 시기에 준우 점종으로 분류되었다.

수직분포에 따른 평균 군집생물량은 $1 \mathrm{~m}$ 에서 $1,773 \mathrm{~g}$ wet $\mathrm{wt} \mathrm{m} \mathrm{m}^{-2}(22.1 \%)$ 와 $5 \mathrm{~m}$ 에서 3,300 g wet wt $\mathrm{m}^{-2}(40.4 \%), 10$ $\mathrm{m}$ 에서 3,093 g wet wt $\mathrm{m}^{-2}(37.9 \%)$ 로 산출되어 수심 $5 \mathrm{~m}$ 와 $10 \mathrm{~m}$ 간에는 큰 차이가 없는 것으로 조사되었으며 계절에 따른 수심별 군집생물량과 종생물량 상위 4 종은 Fig. 4 와 같 다. 강 등 (1993)은 문섬에서 해조분포의 하한선인 $25 \mathrm{~m}$ 수 심까지의 군집생물량을 조사한 바 있으며 $10 \mathrm{~m}$ 이내의 수심 에서는 2,000-3,000 g wet wt $\mathrm{m}^{-2}$ 로 분포한다고 보고하였다. 비록 여름에 국한된 조사 자료이나 본 연구에서 산출된 수심 별 군집생물량과 매우 유사한 결과이다. 봄에는 수심 $5 \mathrm{~m}$ 의 군집생물량이 $42 \%\left(5,042 \mathrm{~g} \mathrm{wet} \mathrm{wt} \mathrm{m}{ }^{-2}\right)$ 를 차지하고 있으며 우점종과 준우점종(Table 2) 이외의 종은 수심 $1 \mathrm{~m}$ 에서 가시 파래(Enteromorpha prolifera), 미역, 수심 $5 \mathrm{~m}$ 에서 미역, 수심 


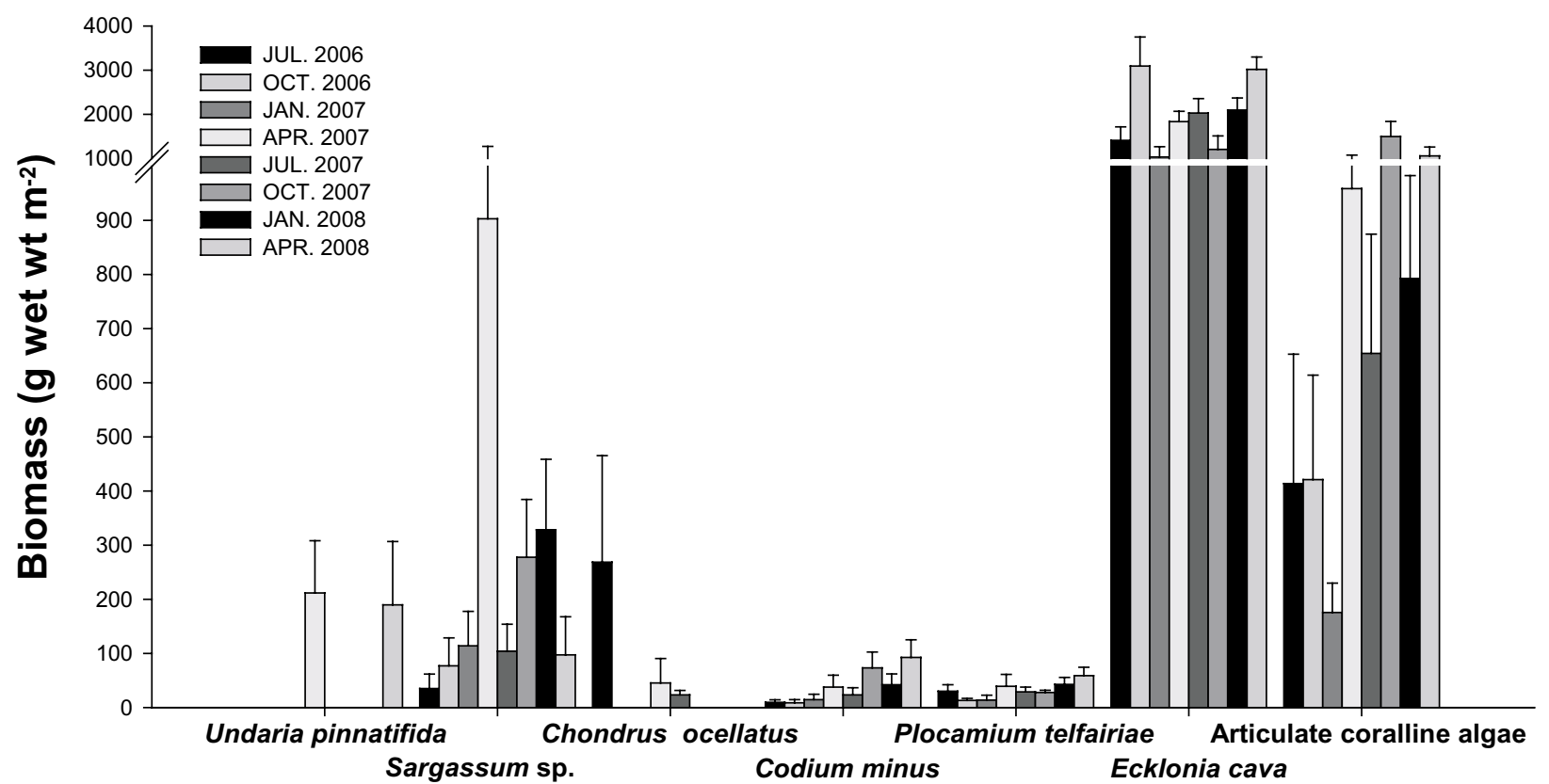

Fig. 3. Seasonal changes in biomass of regressed seven major marine algal species in Munseom. Data are the mean $+\mathrm{SE}$ of 5 replicate at $5 \mathrm{~m}$ and $10 \mathrm{~m}$ depth.
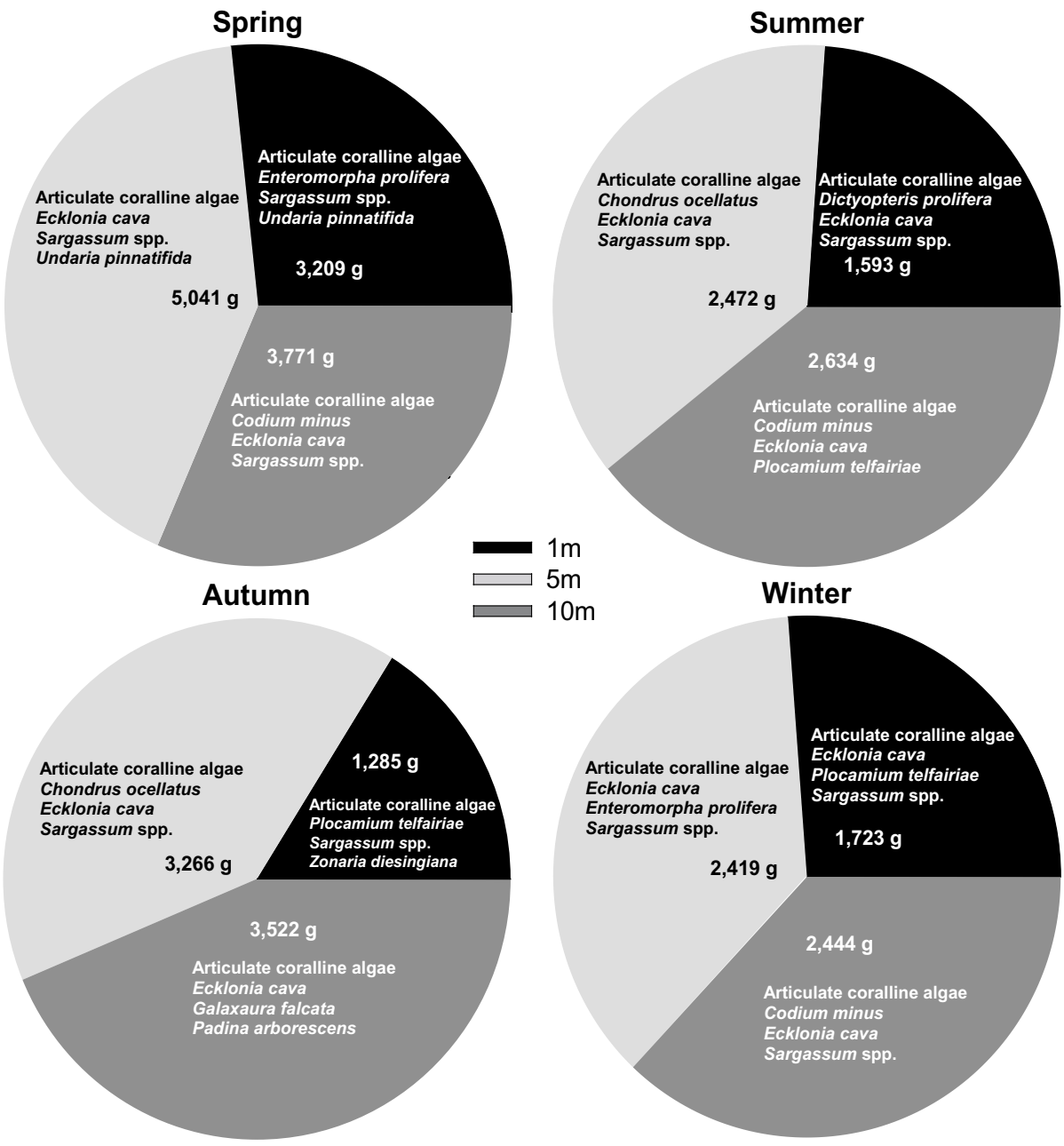

Fig. 4. Vertical distribution of major species biomass (g wet $\mathrm{wt} \mathrm{m}^{-2}$ ) in Munseom. 
$10 \mathrm{~m}$ 에서 구슬청각으로 조사되었다. 여름에는 수심 $10 \mathrm{~m}$ 의 군집생물량 $\left(2,634 \mathrm{~g}\right.$ wet wt $\left.\mathrm{m}^{-2}\right)$ 이 가장 높았으며 주요종은 수심 $1 \mathrm{~m}$ 에서 가시빼대그물말 (Dictyopteris prolifera), 수심 5 $\mathrm{m}$ 에서 진두발, 수심 $10 \mathrm{~m}$ 에서 참곱슬이로 조사되었다. 가을 에는 수심 $1 \mathrm{~m}$ 의 군집생물량이 감소하여 총 생물량 대비 $16 \%\left(1,285 \mathrm{~g}\right.$ wet wt m $\left.\mathrm{m}^{-2}\right)$ 수준에 그쳤으며 주요종은 수심 1 $\mathrm{m}$ 에서 반주름말(Zonaria diesingiana), 참곱슬이, 수심 $5 \mathrm{~m}$ 에 서 진두발, 수심 $10 \mathrm{~m}$ 에서 부챗말(Padina arborescens), 납작 갈라가라(Galaxaura falcata)로 조사되었다. 겨울에는 다른 계 절에 비해 수심별 군집생물량 차이가 크지 않았으며 주요종 은 수심 $1 \mathrm{~m}$ 에서 참곱슬이, 수심 $5 \mathrm{~m}$ 에서 가시파래, 수심 10 $\mathrm{m}$ 에서 구슬청각으로 조사되었다.

본 연구는 제주도 문섬 조하대 군집생물량 산출을 위해 비 파괴적인 방법을 통해 자료를 산출함으로써 군집생물량 조 사를 위해 발생하는 해조군집의 훼손을 최소화하였으며 군 집생물량의 계절별 변동에 대해서도 파악하였다. 추후 지속 적인 연구를 통해 보다 정확한 종생물량과 군집생물량의 추 산을 위해 충분한 사례수에 근거한 회귀공식을 확보하고, 계 절별 회귀공식을 도출하여 문섬지역 해조군집의 생산성을 평가할 수 있을 것으로 기대된다.

\section{사 사}

이 연구는 국토해양부 자원 '해조류를 이용한 온실가스 저감 연구사업 의 일환으로 수행되었다. 초고에 대한 유익한 제안을 해주신 편집위원장님과 논문심사위원님들께 감사 드 린다.

\section{참고문헌}

강래선, 제종길, 손철현. 1993. 남해의 하계 해조군집. 한국수산학 회지 26: 182-97.

고영욱, 성건희, 김정하. 2008. 회귀분석을 이용한 해조류 생물량 측정을 위한 방법론. Algae 23: (inpress)

고철환. 1983. 저서식물의 군집구조와 생산성(동해안, 죽도). 한국 식물학회지 26: 181-190.

고철환, 성낙길. 1983. 저서식물의 군집구조와 생산성(죽도, 동해 안). 한국식물학회지 26: 119-130.

김영식, 김영환, 손철현, 남기완. 1996. 한국 동해 연안역의 저서 해
조류. 한국수산학회지 29: 727-743.

김영환. 1991. 제주도의 해양식물자원. 제주도연구 8: 137-156.

김영환, 박선홍. 1997. 제주도 조간대 해조군집의 천이양식. Algae 12: $23-30$.

김영환, 허성회. 1988 . 서해안 영광원자력발전소 주변 해조군집의 종조성과 생물량. 한국수산학회지 31: 186-194.

남기완. 1986. 동해안 죽도의 해조군집에 관하여. 한국조류학회지 1: 185-202.

남기완, 김영식. 1999. 부산 용호동 일대의 저서 해조상 및 군집구 조. 한국수산학회지 32: 374-384.

박찬선, 고남표, 손철현, 황은경. 1997. 남해안 신지도의 해조군집. 한국수산학회지 30: 574-584.

부성민. 1988. 제주해역 해조류의 분포론적 고찰. 제주도 연구 5 : 97-144.

유종수. 2003. 영일만 내 · 외해역에서 조하대 해조군집 구조의 특 성. Algae 18: 365-369.

윤장택. 1985. 제주도 해조상에 관한 연구. 석사학위논문, 제주대학 교, $31 \mathrm{pp}$.

이기완. 1974. 제주대학 임해연구소 부근의 해조분포 및 식생. Cheju University Journal 6: 269-284.

이용필, 이인규. 1976. 제주도 조간대 해조군락에 대하여. 한국식물 학회지 19: 111-118.

이용필, 이인규. 1982. 제주도 암반 해조자원의 식생분포연구. 서울 대 자연대논문집 7: 73-91.

이해복, 장래혁. 1989. 서해안 태안반도 해조군집변화에 대한 정성 정량적 연구. 한국조류학회지 4: 19-40.

최도성, 김광용, 이욱재, 김지희. 1994. 한국 서남해안 우이도의 해 조상과 군집구조. 환경생물학회지 12: 65-75.

최창근, 곽석남, 손철현. 2006. 동해안 울진 연안 조하대 저서 해조 류의 군집구조. Algae 21: 463-470.

Kang J.W. 1960. The summer algal flora of Cheju Island (Quelpart Island). Bull. Pusan Fish. Coll. 3: 17-23.

Kim K.Y. and Lee I.K. 1995. Community structure of subtidal macroalgae around Neobdo Island on the west-southern coast of Korea. J. Plant Biol. 38: 153-158.

Lee K.W. 1976. Survey of the algal flora of Jeju Island Bull. Mar. Biol. Stat. Cheju Univ. 1: 21-42.

Littler M.M. and Littler D.S. 1985. Nondestructive sampling. In: Littler M.M. and Littler D.S. (eds), Handbook of Phycological Methods. Cambridge University Press, Cambridge. pp. 161175.

Park S.H., Lee Y.P., Kim Y.H. and Lee I.K. 1994. Qualitative and quantitative analyses of intertidal benthic algal community in Cheju Island. Korean J. Phycol. 9: 193-203.

Received 28 October 2008

Accepted 22 November 2008 